УДК 911.5:504.05

DOI https://doi.org/10.32838/2663-5941/2021.2-2/41

Скляр Ю.Л.

Сумський національний аграрний університет

\title{
Kaniнос H.O.
}

Сумський національний аграрний університет

\section{Бузіна I.M.}

Харківський національний аграрний університет імені В.В. Докучаєва

\section{СУЧАСНІ МЕТОДИ ДОСЛІДЖЕНЬ ДЛЯ ФОРМУВАННЯ СТАЛИХ АГРОЛАНДШАФТІВ}

У статті висвітлено питання формування стійких агроландщафтів в умовах створення нових підприємств, які спеціалізуються на видобутку, підготовці, транспортуванні природного газу, газового конденсату та нафти до споживача. Необхідність виконання заходів природоохоронного моніторингу стану трунтового покриву в зонах проведення роботи нафтогазовидобувних підприємств визначена вимогами до рекультивачї порушених територій на майданчиках будівництва свердловин.

Нині значної популярності у світовій практиці для екологічного моніторингу трунтів набули методи дистанційного зондування Землі (ДДЗ). Хімічні методи дають змогу зробити висновок переважно про сучасний стан трунту у точках відбору проб, дистаниійні методи надають можливість оиінити комплекс природних та антропогенних впливів на трунт протягом певного часу у просторі. Найбільш доиільною практикою буде сумісне використання контактних та дистанційних даних.

Актуальним науково-прикладним завданням є створення новітніх і вдосконалення існуючих методів оцінки стану трунтів на основі комплексного використання відомостей контактних і дистанційних методів для пошуку відповідних форм управління екологічною безпекою та стабільного соиіально-екологічного розвитку і земельно-ресурсного потенціалу України.

Нафтогазоконденсатні родовища зазвичай розташовані на сільськогосподарських угіддях. Забруднюючі хімічні сполуки, які надходять у грунт, накопичуються і призводять до поступової зміни хімічних і фізичних властивостей трунту, тим салим погіршуючи його стан і родючість, що у свою чергу впливає на біорозмаїття екосистем.

Головним завданнями агроландшафтного дослідження є класифікачія $і$ зонування агроландшафтів, оиінка їх екологічної стабільності, формування рекомендацій з оптимального використання агроландшафтів і прилеглих територій. Одним із напрямів ландщафтного планування є проектування $і$ конструювання стійких агроландшафтів. У межах агроландшафтного підходу використовуються різні масштаби вихідних картографічних документів (1:100000 - 1:1000), дані дистанційного зондування Землі і польових зйомок.

Ключові слова: ГІС, земельні ресурси, очінка екологічного стану, агроландшафти, нафтогазоконденсатні родовища.

Постановка проблеми. Активне видобування нафти та газу на території України набуває досить поширеного характеру. За останнє десятиліття було створено багато нових підприємств, які спеціалізуються на видобутку, підготовці, транспортуванні природного газу, газового конденсату та нафти до споживача. 3 одного боку, це принесло країні розвиток у економіко-соціальному напрямі, але $з$ іншого - природне середовище зазнало неабиякої шкоди.

Сільськогосподарські угіддя 3 кожним роком зазнають забруднення нафтою та нафтопродуктами, промисловими та побутовими відходами, іншими хімічними речовинами, грунти ущільнюються важкою технікою. Відсутність дієвого контролю за дотриманням елементарних правил, а також порушення сівозмін і норм використання земель призвели до зменшення продуктивності ріллі. Забруднення грунту залишається актуальною проблемою навіть після зниження видобувного навантаження, оскільки продовжується деградація родючого шару, що спричиняє вагому шкоду екосистемі загалом [1, 11 с.].

Аналіз останніх досліджень і публікацій. У сучасному світі нафта $€$ найціннішою корисною копалиною, вона відіграє значну роль у економіч- 
ному розвитку людства. Ї̈і наявність стимулює технологічний процес і полегшує життя людей, але водночас нафта $\epsilon$ найбільшим забрудником навколишнього природного середовища $[1,16$ с.].

Джерелом забруднення можуть бути об'єкти нафто-продуктового забезпечення, це споруди видобування нафти, зберігання та очищення, об'єкти, пов'язані з переробкою та транспортуванням, а також забруднені атмосферні опади. Під час нафтовидобувного процесу одним із головних елементів $\epsilon$ буріння. Буріння розвідувальних та пошукових свердловин, а також експлуатація свердловин дають суттєве навантаження на навколишнє середовище, проте найбільша кількість забруднювальних речовин потрапляє у навколишнє середовище внаслідок аварійних ситуацій $[1,16$ с.].

За поступового збільшення концентрації нафтопродуктів на поверхні грунту спільно з процесами випаровування та розкладання їх летких частинок відбувається процес нагромадження вуглеводнів, що важко розкладаються, таких як: тверді парафіни, циклічні та ароматичні вуглеводні, смоли й асфальтени, які закупорюють пори грунтового покриву [1, 18 с.]. Це призводить до погіршення стану земельних ресурсів, зниження родючості грунтового покриву, техногенного навантаження на агроландшафти.

Постановка завдання. У Качалівській сільській раді Харківської області розпочинається спорудження свердловин Карайкозівського нафтогазоконденсатного родовища. Нині забруднення надходить у агроекосистему тільки від наслідків процесу будівництва, але на території України $\epsilon$ приклади уражених ділянок від нафтових та газових родовищ, тому передбачено встановити допустимий рівень нафтохімічного навантаження та змін фізико-хімічних властивостей грунтів, а також провести оцінку можливих перспектив подальшого використання деградованої території.

Виклад основного матеріалу. На території розташовано сільськогосподарське підприємство СТОВ «УкрАгроСтар», але на його землях проводиться розробка Карайкозівського нафтогазокондинсатного родовища, яке нині проходить облаштування із побудовою газопроводу довжиною 16675 м. Споруда частково прокладатиметься на орних землях сільськогосподарських угідь.

Переважно спорудження нафтових свердловин проводять на сільськогосподарських угіддях, які під час спорудження свердловин не використовують для вирощування сільськогосподарських культур та як пасовища для худоби, згідно 3
Вимогами [2, 23 с.]. А у подальшому експлуатація видобувних свердловин у відповідності з технологічними регламентами не буде впливати на стан грунтового покриву.

У процесі розробки родовища (2,9 га) деякі зони ландшафту зазнали просторових змін - виникли технологічні споруди та об'єкти, що мінімізували естетичну привабливість геокомплексу та сформований природний вигляд, властивий локальній території. Під час виконання планованої діяльності та проведення робіт із перебудови функціонуючих об'єктів подальших негативних впливів на рельєф не передбачається. Земельна ділянка, необхідна для спорудження проектної свердловини, знаходиться на землях Качалівської сільської ради, за межами населених пунктів.

Особливу зацікавленість викликає дослідження територіальної структури агроландшафтів, яка створюється і функціонує внаслідок постійного взаємозв'язку сільськогосподарського виробництва і природного середовища. Актуальність агроландшафтних вивчень визначається необхідністю збільшення продуктивності сільськогосподарських угідь за збереження їх природно-ресурсного потенціалу.

Головними завданнями агроландшафтного дослідження є класифікація і зонування агроландшафтів, оцінка їх екологічної стабільності, формування рекомендацій $з$ оптимального використання агроландшафтів і прилеглих територій. Одним із напрямів ландшафтного планування $\epsilon$ проектування і конструювання стійких агроландшафтів [3, с. 97,4 , с. 53$]$.

Майданчики та територія нормативної санітарно-захисної зони (С33) знаходяться на сільськогосподарських угіддях (рілля). Землі С33 для вирощування сільськогосподарських культур, пасовищ для худоби під час спорудження свердловин використовуватися не будуть (рис. 1).

Значущість агроландшафтознавства полягає у створенні уніфікованої моделі даних агроландшафту, орієнтованої на застосування в середовищі інструментальних ГIC типу MapInfo або ArcGIS [5, c. 29,6 , c. 199].

У межах агроландшафтного підходу використовуються різні масштаби вихідних картографічних документів (1:100 000 - 1:1000), дані дистанційного зондування Землі і польових зйомок. Через різницю використовуваних просторових і часових масштабів, різні методики і технології польових і картографічних робіт результати таких робіт мають поширення тільки в межах певної наукової школи, і тому їх важко порівняти між собою. 


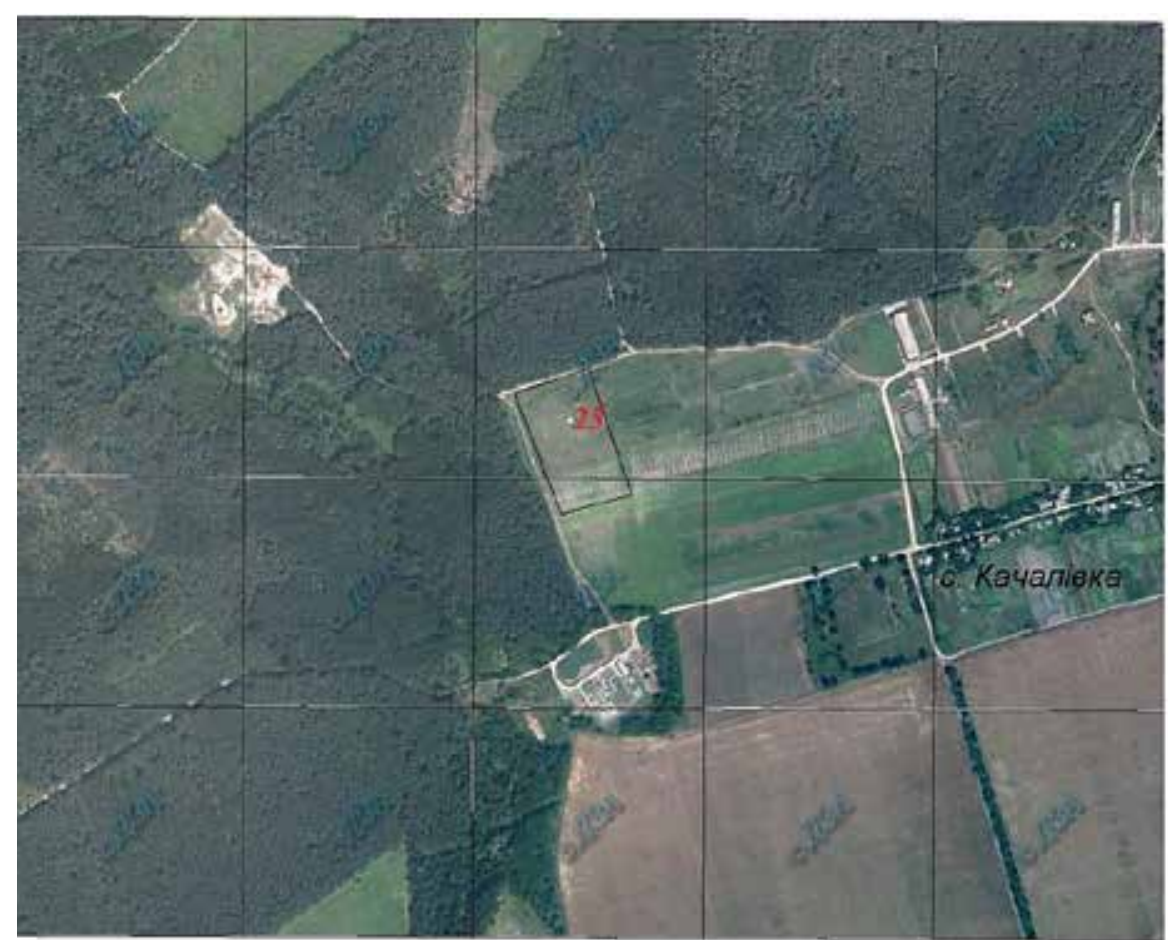

Рис. 1. Схема розташування бурового майданчика свердловини № 25

Модель відомостей агроландшафтів являє собою набір об'єктів і їх специфікацій для картографічних баз даних та допоміжних таблиць, склад яких варіюється залежно від масштабу і цілей вивчення. Склад картографічної бази даних включає: блоки компонентів агроландшафту, агроландшафти декількох ієрархічних рівнів, довідково-нормативні дані з агротехнологій та охорони навколишнього середовища [5, с. 29].

Оскільки на буровому майданчику свердловини № 25 знаходяться малоцінні грунти із вмістом гумусу менше $1 \%$, для збереження родючого шару грунту від забруднень зняття і складування його в кагати 3 наступною укладкою на попереднє місце після закінчення бурових робіт для цих грунтів не потрібно. Після закінчення бурових робіт передбачено проведення технічного та біологічного етапів рекультивації (рис. 2).

Але все ж таки гумусовий шар грунту у процесі спорудження свердловин може зазнавати впливу землерийної, навантажувальної і транспортної техніки, яка використовується під час підготовчих та монтажних робіт; відпрацьованого бурового розчину з хімреагентами; бурових стічних вод; мінералізованих вод під час фонтанування.

Унаслідок спорудження похило-спрямованих свердловин із метою пошуків вуглеводнів у перспективних горизонтах серпухівських та візейських відкладів нижнього карбону з розкриттям девонської солі Карайкозівського родовища № 25
(2,9 га), а також через економічні та інші причини, складні сучасні ринкові умови спостерігається погіршення агроекологічного стану грунтів, розвиток на них процесів деградації грунтів - ерозії, дегуміфікації, переущільнення, зменшення біорізноманіття тощо.

За ступенем змитості, еродованості та крутизни схилів земель Качалівської сільської ради Краснокутського району можна поспостерігати на рис. 3.

Головна ідея полягає в ландшафтному структуруванні місцевості 3 метою створення агроландшафтів із деякими особливостями саморегулювання, що досягається двома нероздільно пов'язаними принципами:

- формуванням стоковідвідної контурно-смугової системи робочих зон, що гарантує безпечну діяльність води на полях;

- дотриманням раціональної виробничої технології, яка зумовлює збереження значної водовбирної можливості та протиерозійної стабільності грунтів [7, с. 4, 8, с. 170].

Короткотривале вилучення територій із сільськогосподарського обігу 3 метою побудови або капітального ремонту свердловин може володіти негативними наслідками, такими як ускладнення агрофізичних, агрохімічних якостей та забруднення важкими металами грунтів рекультивованих бурових майданчиків. Прояви деградації грунтового покриву такої штучно 


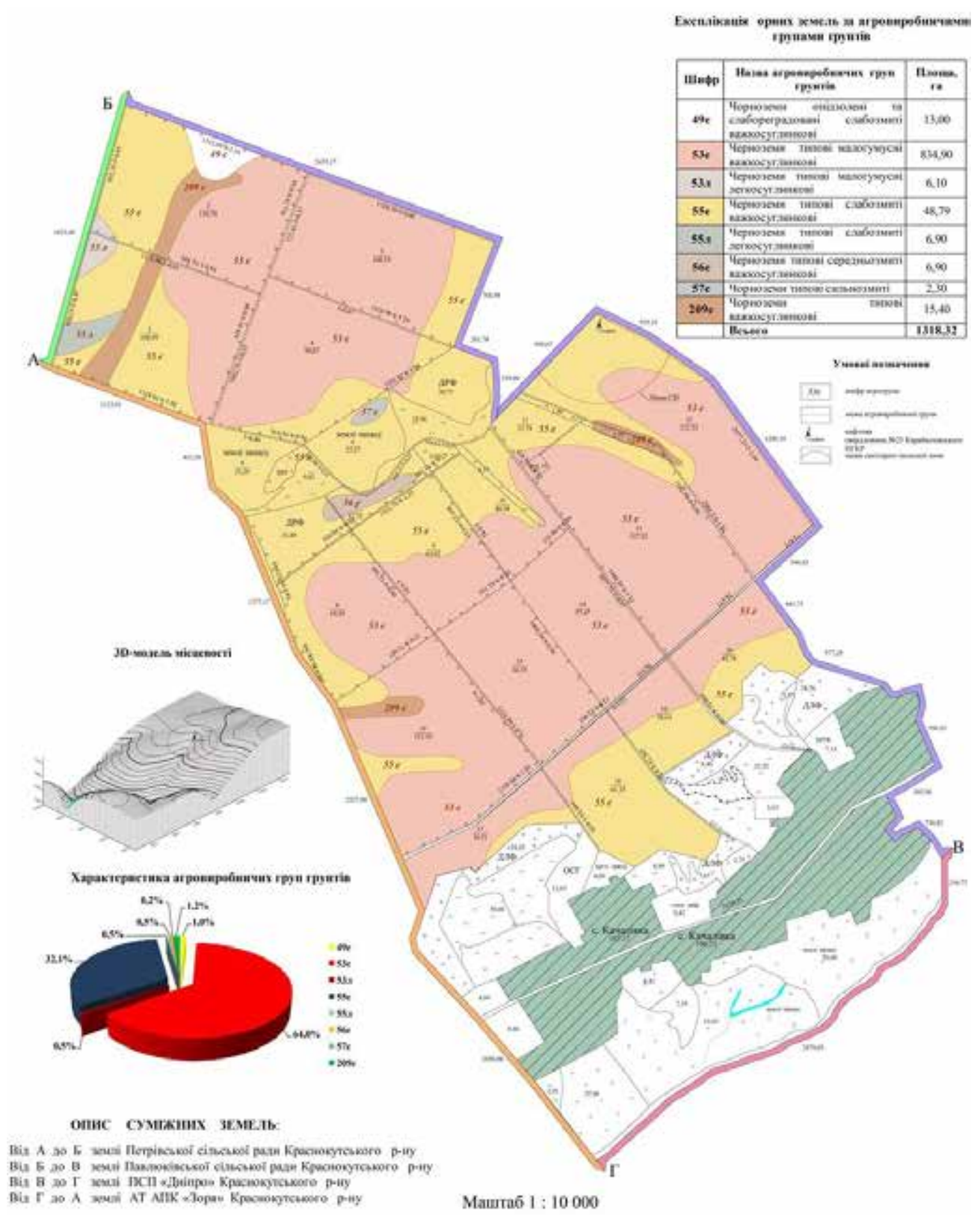

Рис. 2. Схема агровиробничих груп грунтів СТОВ «УкрАгроСтар»

створеної системи агроландшафту вважаються стійкими і довготривалими, як наслідок, простежується скорочення родючості грунтів, а в окремих випадках можлива і повна їі втрата [9, с. 148]. Геохімічна і фізична трансформація грунтів починається вже на стадії будівництва бурових майданчиків.

Характеристики територій бурових майданчиків показують площі порушених (модифікованих) територій, рівень і вид техногенних змін. Основними заходами, які наблизять до вирішення цієї проблеми, є: проведення розрахунку внесення мінеральних добрив (N, P, K); внесення напіврозкладеного гною в нормі $45 \mathrm{~T} /$ га; застосування вологозберігаючих технологій обробітку грунту, в тому числі проведення щілювання; передпосівне боронування, прикоткування посів суміші бобових і злакових трав і післяпосівне прикоткування грунту; утримання грунту під багаторічними травами протягом 2 років.

У результаті розрахунку екологічної стабільності територія виявилася екологічно нестабільною.

Коефіцієнт антропогенного навантаження:

$$
\frac{\sum(K 1 i \cdot P 1)}{\sum \mathrm{Pi}} \mathrm{Kp}=\frac{376,15}{1609,72} \cdot 1=0,23,
$$

де: К1і - коефіцієнт екологічної стабільності угіддя і-го виду;

$\mathrm{Pi}$ - площа угідь і-го виду; 


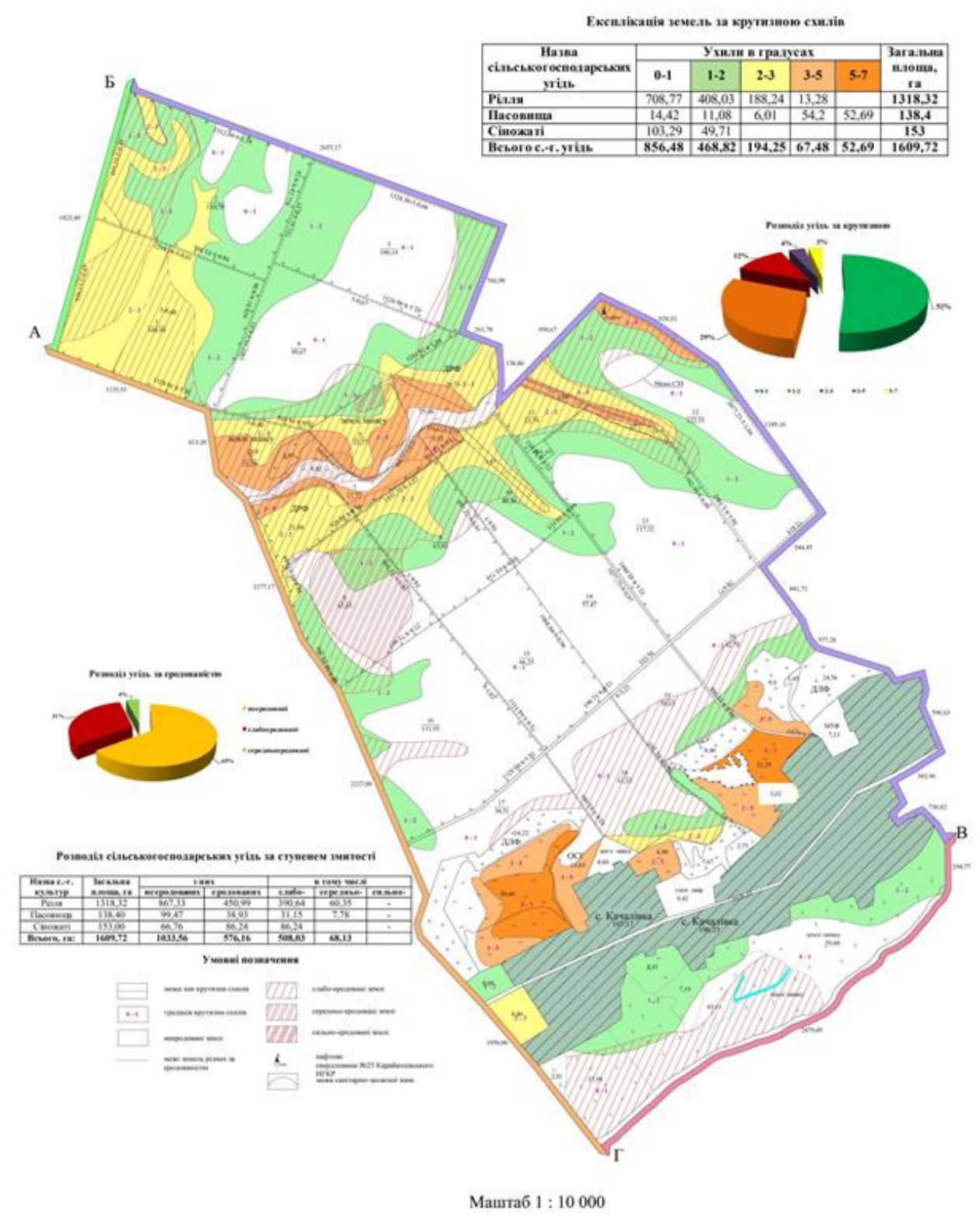

Рис. 3. Крутизна схилів та еродованість земель

Кр - коефіцієнт морфологічної стабільності рельєфу (Kp $=1,0$ - для стабільних територій $\mathrm{i}$ Кр $=0,7$ для нестабільних територій).

Таким чином, табл. 1 показує агроекологічну оцінку грунтів, яка вимірюється за 10-бальною шкалою. Досліджувана територія екологічно нестабільна, має високий рівень антропогенного навантаження та помірний рівень ерозійної небезпеки.

Припинення ерозійно-дефляційних втрат грунту можливе лише за умов безперервного використання грунтозахисних технологій, протиерозійного облаштування агроландшафтів на контурно-меліоративних засадах, організації постійно діючого оперативного моніторингу стану ерозійно-небезпечних територій за допомогою методів дистанційного зондування грунтово- рослинного покриву з використанням дистанційних методів.

Висновки. Поступове збільшення концентрації нафтопродуктів на поверхні грунту спільно 3 процесами випаровування та розкладання їх летких частинок призводить до нагромадження вуглеводнів, що важко розкладаються і закупорюють пори грунтового покриву.

Після будівництва газопроводу проектом закладено проведення рекультивації, передбачено відновлення земель до стану, придатного до використання в сільському господарстві. Для приведення родючості деградованих грунтів у нормалізований стан знадобиться щонайменше 3 роки. Найважливішим заходом збереження грунтів $\epsilon$ правильне формування культурного 
Таблиця 1

Узагальнена оцінка території у балах

\begin{tabular}{|l|l|c|}
\hline \multicolumn{1}{|c|}{ Назва показника } & \multicolumn{1}{|c|}{ Значення показника } & Бал \\
\hline Коефіцієнт екологічної стабільності & 0,23 -екологічно нестабільна територія & 2 \\
\hline Коефіціснт антропогенного навантаження & 3,80 & 3 \\
\hline Коефіцієнт розораності, \% & 81 & 4 \\
\hline Коефіціснт лісистості, \% & 0,9 & 1 \\
\hline Перевищення допустимої розораності, \% & 19 & 8 \\
\hline Індекс збереження грунтів, роки & $128-$ помірна небезпека \\
\hline
\end{tabular}

агроландшафту. У кожній екосистемі має бути своє науково обгрунтоване співвідношення угідь. Це забезпечить комплексність проведення заходів і захист довкілля.

В Україні використання даних супутникового зондування в сільському господарстві нині
$€$ перспективним напрямом, що швидко розвивається. Матеріали космічної зйомки та сучасні ГІС-технології використовують як для вирішення комплексних завдань управління сільськогосподарськими територіями, так і у вузькоспеціалізованих напрямах.

\section{Список літератури:}

1. Качала Т.Б. Удосконалення систем екологічного моніторингу грунтового покриву виснажених нафтогазових родовищ. Прикарпаття: дис. ... канд. тех. наук: 21.06.01. Івано-Франківськ, 2018. 158 с.

2. Державні санітарні правила планування та забудови населених пунктів: Наказ МОЗ України від 19.06.1996 р. № 173 зі змінами за наказом від 02.07.2007 р. № 362, 1996. № 379/1404.

3. Максименко Н.В., Михайлова К.Ю. ГІС-моделювання агроландшафтів для потреб ландшафтного планування. Людина та довкілля. Проблеми неоекології / Харк. нац.ун-т імені В.Н. Каразіна. Харків, 2013. 94-105 c.

4. Opara, V., Buzina, I., Khainus, D., Vynohradenko, S., \& Kovalenko, L. (2020). Теоретичні й методичні основи використання ГІС-технологій та створення електронних карт при проведенні землеустрою. Проблеми безперервної географічної освіти і картографії, (31), 50-59. https://doi.org/10.26565/2075-1893-2 020-31-06

5. Дмитрик П.М. Геоінформаційні системи агроланшафтів і основи геостатистики: конспект лекцій. Івано-Франківськ: ДВНЗ ПНУ, 2018. 77 с.

6. Opara, V., Buzina, I., \& Khainus, D. (2019). Картографування ландшафтно-екологічних дослідженнь території дендрологічного парку ХНАУ ім. В.В. Докучаєва. Вісник Харківського начіонального університету імені В. Н. Каразіна, Серія «Геологія. Географія. Екологія», (50), 197-209. https://doi.org/10.26565/2 410-7360-2019-50-15

7. Ачасов А.Б. Протиерозійне впорядкування агроландшафту на основі математичного моделювання ерозійних процесів: науковий посібник / Держ. уст. «ДНТ центр охорони родючості грунтів». Київ, 2012. 3-10 с.

8. Бузіна І.М., Коломієць С.М., Леженкін I.О. Геоінформаційні технології для оцінки стану земельних ресурсів та управління на рівні адміністративного району // Вчені записки. - 2020. - С. 168-173.

9. Уразовська М.К. Спорудження пошукової похило-спрямованої свердловини № 48 Карайкозівського НГКР проектною глибиною 6150м 3 метою пошуків вуглеводнів у відкладах серпуховського та візейського ярусів нижнього карбону. Краснокутський район Харківської області. Харків, 2020. 343 с.

\section{Skliar Yu.L., Kapinos N.O., Buzina I.M. MODERN RESEARCH METHODS FOR FORMATION OF SUSTAINABLE AGROLANDSCAPES}

The article highlights the formation of sustainable agricultural landscapes in the creation of new enterprises specializing in the production, preparation, transportation of natural gas, gas condensate and oil to the consumer. The need to implement environmental monitoring measures of the soil cover in the areas of oil and gas companies is determined by the requirements for reclamation of disturbed areas at construction sites.

At present, remote sensing methods of the Earth (DDZ) have gained considerable popularity in the world practice for ecological monitoring of soils. Chemical methods allow to draw a conclusion mainly about the current state of the soil at the sampling points, remote methods provide an opportunity to assess the complex of natural and anthropogenic impacts on the soil over time in space. The most appropriate practice will be the combined use of contact and remote data. 
At the level of the current scientific and applied task is to create new and improve existing methods of soil assessment based on the integrated use of contact and remote sensing methods to find appropriate forms of environmental safety management and provide stable socio-ecological development and land resources of Ukraine.

Oil and gas condensate fields are usually located on agricultural land. Pollutants that enter the soil accumulate and lead to a gradual change in the chemical and physical properties of the soil, thereby deteriorating its condition and fertility, which in turn affects the biodiversity of ecosystems.

The main tasks of agro-landscape research are the classification and zoning of agro-landscapes, assessment of their ecological stability, formation of recommendations for optimal use of agro-landscapes and adjacent territories. One of the areas of landscape planning is the design and construction of sustainable agricultural landscapes. The agro-landscape approach uses different scales of original cartographic documents (1: 100000 - 1: 1000), data of remote sensing of the Earth and field surveys.

Key words: GIS, land resources, ecological assessment, agrolandscapes, oil and gas condensate fields. 